\title{
Molecular Diagnosis of Brucella species in Baghdad
}

\author{
Inas Saad mohammed * Khaled A. Habeb * \\ Ashna Jamal Faik**
}

Received 8,September,2011

Accepted 18,January,2012

\begin{abstract}
:
Brucellosis is possess a significant public health problem in Baghdad. In this study, we investigated the potential role of the PCR assay in detection of Brucella species, from patients suspect to have brucellosis, using blood samples in both human and animal.

To establish a PCR technique for diagnosis of active brucellosis in our samples, DNA extraction was carried out using a commercial kit, and a laboratory extraction procedure. PCR amplification was done using 1 set of primers: B4/B5 for Brucella species. Extraction of Brucella DNA using the commercial kit was successful. The laboratory extraction was successful and more economic.

A total of 178 peripheral blood specimens were collected from patients with high suspected brucellosis, and 15 samples from animals. When PCR technique was applied to blood samples, 13 cases for patients blood and 9 cases for animals blood, were positive for Brucella species.
\end{abstract}

Key Words: Brucellosis, PCR, Baghdad.

\section{Introduction:}

Brucellosis possess a significant public health problem in Baghdad and many developing countries which requires fast and accurate diagnosis. Brucellosis is a chronic infectious disease caused by bacteria of the genus Brucella that affects animals and humans. Each species of Brucella has its preferred host: B. abortus infects cattle, $B$. melitensis infects sheep and goats, $B$. suis infects swine, $B$. canis infects dogs, and $B$. ovis infects sheep, although they can also infect other animals [1]. Brucellosis in sheep and goats is endemic in the Mediterranean region but is spread throughout Asia, Africa, and Central and South America $[2,3]$. Along with tuberculosis and rabies, brucellosis is the most important bacterial zoonosis and remains an important public health and economic concern All Brucella species can cause infection in human exception of B. ovis and B. neotomae. New Brucella species pathogenic for humans - B. cetaceans and $B$. pinnipedialis - have recently been discovered in marine mammals [4]. Which is transmitted to humans either by direct contact with the infected animals or by consuming infected milk or fresh cheese [1].

Another major infection route is through occupational exposure to infected live stock, ie, inhalation of contaminated secretions of infected animals or contamination through skin cuts or abrasions [5, 6]. Clinically, brucellosis can be classified into subclinical, acute, subacute, and chronic relapsing forms. Clinical polymorphism is very common and for this reason brucellosis is often unrecognized in primary health care settings [7].Exact diagnosis is based on the clinical picture, epidemiological

\footnotetext{
* Department of Biology; College of Sciences for Women; Baghdad University.

**Center Public Health Laboratory/ Ministry of Health
} 
data, and different laboratory tests, such as bacterial culture, agglutination, and polymerase chain reaction $[8,9]$.

PCR assay has been used in diagnosis both animal $[10,11]$ and human $[10$, 12, 13]. PCR technique provides rapid diagnosis of brucellosis, which is necessary for

starting a specific patient treatment In this study, we investigated the potential role of the PCR technique in the diagnosis of human and animal brucellosis using whole blood.

\section{Materials and Methods:}

A total of 178 peripheral blood specimens were collected from patients with high suspected of brucllosis, referred to Al-Yarmook, Al-Karama, Al-Shaheed Al-Sadder, Al-Imam Ali (peace be upon him) and Al-Kadhmiya Hospitals in Baghdad, and 15 peripheral blood and milk specimens were collected from animals, referred to Al- Fudhailiyah and Al-Husainia regions in Baghdad, during the period from November 2009 till November 2010. Samples were taken from patient suspected to be with brucellosis depending on clinical picture [14], a positive Rose Bengal test titer of $\geq$ $1: 160$, and/or a positive blood culture, moreover demographic, occupational, clinical, and risk factor details were recorded for each patient, and serological diagnosis was carried by positive Rose Bengal test and ELISA test.

\section{Culture and biochemical testst:}

Five milliliters of blood were taken from each patient and animals and divided into identical parts. One part was collected in EDTA and the serum was separated from the second part, was aliquot and store at $-20^{\circ} \mathrm{C}$ until processing. The first part of the blood with anticoagulant was inoculated into: Blood Agar Base, Brucella agar, trypticase soya agar and trypticase soya broth culture medium containing both a solid and a liquid phase [15]. Then it was subculture on duplicate agar plates and incubated one in air and the other in an atmosphere at $37^{\circ} \mathrm{C}$ in the presence of $5-10 \% \mathrm{CO}_{2}$.After 730 days, colonies grown in the solid phase, were identified by inoculation into Brucella agar, blood agar and trypticase soya agar.

DNA extraction from blood samples: Genomic DNA was extracted from blood and bacterial culture of Brucella spp. using a Wizard Genomic DNA Purification Kit / Promega - company (USA). This kit is designed to isolate genomic DNA from white blood cells.

\section{PCR for Brucella species:}

Tow PCR methods were used. Samples were tested in duplicate in most cases. The primer B4 (5'TCGGTTGCCAATATCAA-3') and B5 (5'CGCGCTTGCCTTTCAGGTCTG-3`) [16],were used to amplify a target sequence of (223bp) in a gene encoding a $31-\mathrm{KDa}$ in B.abortus This sequence has been shown to be common to all Brucella biovar. The PCR was perform in $50 \mu 1$ reaction mixture containing: $31.75 \mu \mathrm{l} \sim 32 \mu \mathrm{l}$ $\mathrm{H}_{2} \mathrm{O}, 10 \mu \mathrm{l} 10 \mathrm{x}$ PCR buffer, $1 \mu \mathrm{l}$ (dNTPs) mix (200 mM) deoxyribonucleoside triphosphate (d ATP, d GTP, d CTPm, d TTP), $3 \mu 1$ $\mathrm{MgCl}_{2}, 2 \mu \mathrm{l}$ for each oligonucleotides

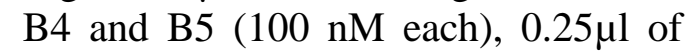
Taq polymerase, $2 \mu \mathrm{l}$ of samples DNA.

The PCR was started as in the following steps:-

1-Denaturation 1 at $93^{\circ} \mathrm{C}$ for 5 min.

2- 35cycles of:-

A-Denaturation 2 at $90^{\circ} \mathrm{C}$ for 2 min.

B-Annealing at $60^{\circ} \mathrm{C}$ for 2 min.

C-Extension 1 at $72^{\circ} \mathrm{C}$ for 2 min.

3- Extension 2 or final extension at $72{ }^{\circ} \mathrm{C}$ for $4 \mathrm{~min}$.

The last step is (extention 2 or final extention) according to [17]. 
The PCR products plus 100 bp DNA Ladder were subjected to electrophoresis on $2 \%$ agarose gel stained with Ethidium bromide. Electrophoresis was performed at $70 \mathrm{~V}$ for $60 \mathrm{~min}$. The gel was visualized on UV transilluminator at $320 \mathrm{~nm}$ and was photographed by polaroid system.

\section{Results:}

A total of 178 peripheral blood specimens have been collected from suspected brucellosis patients. The diagnosis of brucellosis was established by clinical findings confirmed by Rose Bengal test, ELISA, blood culture and molecular methods by PCR technique. They were divided into two groups, acute cases with duration of symptoms less than 6 months and

chronic cases with duration of symptoms more than 1 year. Thus, among these patients, $10(5.61 \%)$ were chronic cases and $22(12.35 \%)$ were acute cases of total 178 cases. In addition 15 samples were obtained from animals. The diagnosis of brucellosis was based on abortion fetus or infected new born and confirmed by serological test (Milk ring test), blood culture and molecular methods by PCR technique.

All patients gave a history for their disease. SO 150(84.26\%) were lived in epidemic area and consuming unpasteurized milk and milk products; and $28(15.73 \%)$ were farmers or butchers or they are lived near animals. A total of $178(89 \%)$ blood samples were cultured using plates of BAM and TSAM for isolation of Brucella species, showed no results for culture but a total of 15 blood samples were cultured using plates of BAM and TSAM for isolation of Brucella species, only 3 were positive. The round, glistening, small, convex colonies on plates of BAM were suspected to be of Brucella. The isolates were streaked on blood agar (BA) plates. The non-haemolytic and have a small pale shape isolates on BA. In present study DNA extracted from 178 human blood samples, 178 (100\%) samples were positive results and 15 animals, $15(100 \%)$ blood samples and 3 (20\%) blood culture samples were positive results by the Wizard Genomic DNA Purification Kit ( Promega - company -USA) was used and subjected to PCR using different primer pairs.

When PCR technique was applied to blood samples, 13cases $(7.30 \%)$ of total178 patients and 9 cases (60\%) of total 15 blood animals, were positive and gave (223bp) for Brucella specific-species bands (figure-1and 2) Figure-1: the diagnostic results of PCR technique for 3 cases for patients for B4 and B5 (223bp). Figure-2: the diagnostic results of PCR technique for 9 cases for animals for B4 and B5 (223bp). 


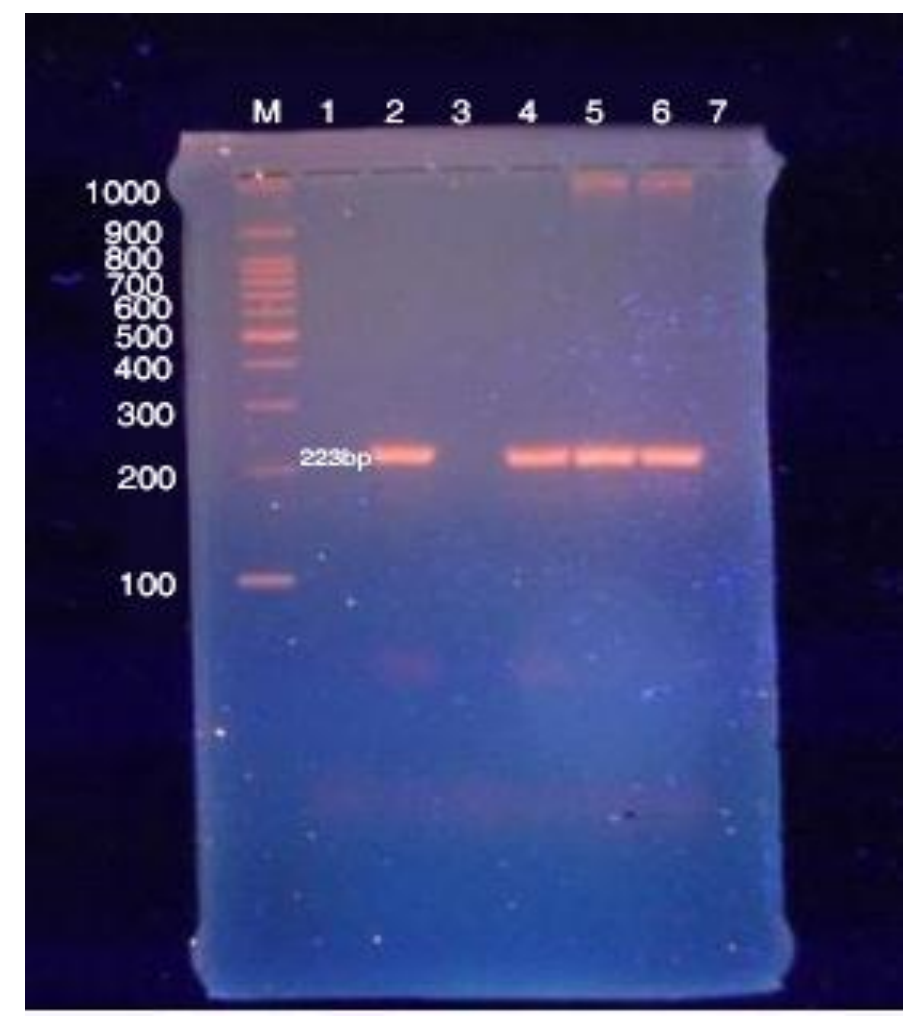

Figure 1: Agarose Gel Electrophoresis for Human of Brucella 31-KDa Gene $223 \mathrm{bp}$ Specific PCR Products Amplified with Primer B4/B5.

Lane M, molecular weight DNA ladder (100bp), lane 1: negative control, lane 2:B4/B5 positive control (223bp), lanes 4, 5, 6: positive samples, lane 3, 7: negative samples.

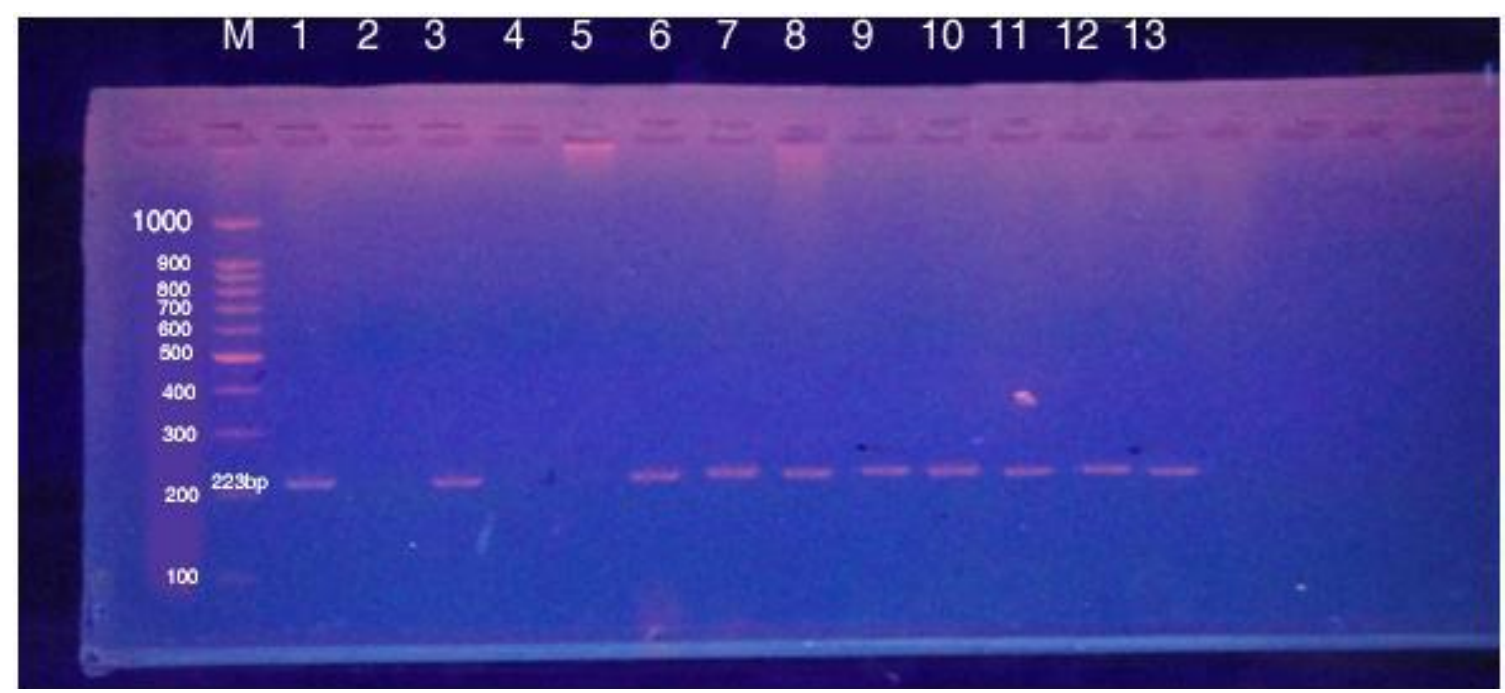

Figure 2: Agarose Gel electrophoresis for Animal of Brucella 31-KDa Gene $223 \mathrm{bp}$ Specific PCR Products Amplified with Primer B4/B5.

Lane M, molecular weight DNA ladder (100bp), lane 1:B4/B5 positive control, lane 2: negative control, lane $3,6 \rightarrow 13$ : positive samples, line 4, 5: negative samples. 


\section{Discussion:}

Brucellosis has a worldwide distribution and remains a major problem in human and animals. Brucellosis is also a health problem for humans and animals and causes economic loss due to the loss of animals. The study revealed that brucellosis increases in rural area about $115(64.60 \%)$ more than urban area about $63(35.39 \%)$ according to ELISA for both

$\operatorname{IgM} 10$ (5.61\%) and $\operatorname{IgG} 22$ (12.35\%). Therefore, people in rural area were lived in epidemic area, contact with animals like: owner of the herds, their family members because were used unpasteurized milk, cheese and milk product from the infected cows or by the long exposure time of the people to the infected animals inside their house; and pupils in urban area were farmers, butchers or they lived near animals, or pupils which drink milk without boiling or eat unboiled cheese were exposed to this disease. The emphasizes that the farmers and butchers working with livestock were infected with Brucella. This helps us to realize that boiling milk

and cheese before consumption which is a very simple and uncostly step can reduce disease infection.

Human blood samples showed no results for culture out of 178 samples, because all patients use different longterm antibiotic treatments for various diagnostic suspicions in other clinical sectors, so that affected culture method. Also [18] (2004) concluded that there are clinical and serological finding to support the presence of brucellosis in patients with negative blood culture and positive PCR. While culture as a reference, 3 (20\%) samples were positive by culture and 12 (80) samples were negative out of 15 animal's blood samples which their causes from aborting fetus or infected new born. The explanation for the low yield of conventional culture in present study appears to be related more to the low number of pathogen in the blood sample and use of the different antibiotic treatments for various diagnostic suspicion in other clinical sectors. In spite of difficulty of isolation Brucella species from animals blood samples. Hence makes PCR more sensitive than culture while the specificity was $100 \%$ and identical to culture so; suggest that PCR could replace blood culture as the gold standard for the diagnosis of animals blood samples. [19] (2004) who analyzed samples obtained from 67 aborted bovine fetuses by means of bacteriological methods and PCR and also found that the samples that were positive by PCR $(34 / 67)$ more than that of culture (26/67), so he concluded that PCR was more sensitive than culture. Using blood culture as a gold standard, the PCR technique gave a100\% sensitivity, which is in agreement with other authors [12, 20]. Although most investigators prefer using commercial kits for extraction of Brucella DNA $[13,21,22]$. We successful to extract DNA by a commercial kit. We used a laboratory extraction procedure according to Wizard Genomic DNA Purification Kit / Promega - company -USA.

Our results showed that the sensitivity of the PCR assay using blood samples for patients and using blood samples for animals was far superior 13 (7.30\%) for patients and $9(60 \%)$ for blood animals, were positive and gave (223bp) for Brucella species This very good sensitivity, confirm that the PCR assay could be a useful tool for the diagnosis of human brucellosis as other investigators showed by using whole blood [12, 23] or serum samples [20]. Finally, in addition to the high yield of the PCR assay for the diagnosis of human brucellosis according to present study, and focal complications in such 
patients as previously reported [23], other important aspects are: 1) PCR is fast, providing results in 24 hour, which is much less than the time required for conventional methods to rescue a fastidious microorganism such as Brucella spp., 2) the technique almost completely obviates the necessity for direct handling of the pathogen, thus drastically reducing the risk of infection of laboratory personnel, and 3) the samples can be stored at $-20^{\circ} \mathrm{C}$ until processing, thus enabling it to be collected by any physician and processed immediately, or else stored and safely sent to another laboratory if necessary.

\section{References:}

1. Seleem, M.N., Boyle, S.M., Sriranganathan,N 2010 Brucellosis: a re-emerging zoonosisVet Microbiol. 140:392-8.

2. Taleski,V., Zerva, L., Kantardjiev, T., Cvetnic, Z., Erski-Biljic, M., Nikolovski, B 2002 epidemiology and epizootology of brucellosis in selected countries of the An overview of

Central and Southeast Europe. Vet Microbiol. 90:147-55.

3. Caprine and ovine brucellosis. 2009 In: Manual of diagnostic tests and vaccines for terrestrial animals. Paris: Office international des epizooties. P.1-10.

4. Foster, G., Osterman, B.S., Godfroid, J., Jacques, I., Cloeckaert, A 2007 Brucella ceti. and Brucella pinnipedialis for Brucella strains with cetaceans and seals as their preferred hosts. Int $J$ Syst Evol Microbiol.57:2688-93.

5. Namanda, A.T., Kakai, R., Otsyula, M. 2009 The role of unpasteurized "hawked" milk in the transmission of brucellosis in Eldoret municipality, Kenya. $J$ Infect Dev Ctries. 3:260-6.

6. Bosilkovski, M., Krteva, L., Dimzova, M., Kondova, I. 2007 Brucellosis in
418 patients from the Balkan Peninsula: exposure-related differences in clinical manifestations,

laboratory test results, and therapy outcome. Int J Infect Dis.; 11:342-7.

7. Buzgan, T., Karahocagi, M.K, Irmak, H., Baran, A.I, Karsen, H., Evirgen, O. (2010). Clinical manifestations and complications in1028 cases of brucellosis: a retrospective

evaluation and rewiew of the literature. Int J Infect Dis. 14: 469-78.

8. Sauret, J.M.and Vilissova, N. (2002) Human brucellosis. J Am Board Fam Pract.15:401-6.

9. Tabak,F., Hakko, E., Mete, B., Ozaras, R., Mert, A., Ozturk, R.(2008). Is family screening necessary in brucellosis? Infection. 36:575-7.

10. Leal-Klevezas,D.S., MartinezVazquez, I.O., Martinez-Soriano, J.P1995 Single-step PCR for detection of Brucella spp. From blood and animals of infection animals. J. Clin. Microbiol. 33, 3087- 3090.

11. Leal-Klevezas,D.S., MartinezVazquez, I.O., Garcia-Cantu,J., LopezMerino, A., Martinez Soriano, J.P. 2000 Use of polymerase chain reaction to detect Brucella abortus biovar1 in infection goats.Vet. Microbiol. 75, 91-97.

12. Queipo-Ortuno, M.I., Morata, P., Ocon,P., Manchado, P., Colmenero, J.D. 1997 Rapid diagnosis of human brucellosis by peripheral blood PCR assay . J Clin Microbiol 35:29272930.

13. Nimir, L.F. 2003Diagnosis of recent and relapsed cases of human brucellosis by PCR assays.BMC Infect Dis 3:5.

14. World Health Organization. 1998 Surveillance of Communicable Diseases: A Traninig

Manual. Geneva: Regional Office for the Eastern Mediterranean. WHO$\mathrm{EMm} / \mathrm{CDS} / 52 \quad / \mathrm{E} / \mathrm{L}$. 
15. Yagupsky, P1999 Detection of brucella in blood cultures. J Clin Microbiol .37: 343742.

16. El Kholy, A.A.; Gomaa, H.E.; El Anany, M.G.; Abd El Rasheed, E. 2007 1(2):177-181.

Diagnosis of human brucellosis in Egypt by PCR.

17. Morata,P., Queipo-Ortuno, M.I. Colmenero, J.D1998Strategy for optimizing DNA amplification in a peripheral blood PCR assay used for the diagnosis of human brucellosis

J Clin Microbiol 36:2443-2446.

18. Navarro, E., Casao, M., Solera, J. 2004 Diagnosis of human brucellosis using PCR. Expert Reu. Mol. Diagn. 4 (1) p. 115-123.

19. Scarcelli, E., Piatti, R., Cardoso, M., Miyashiro, S., Campos, F., Teixeira, S., Castro, V., Genovez, M. 2004 Detection of bacterial agents by isolation and identification and multiplex PCR in aborted bovine fetuses. Revista Brasileira de Reproducao Animal 28:23-27.
20. Zerva, L., Bourantas, K., Mitka, S., Kansouzidou, A., Legakis NJ. 2001 Serum is the preferred clinical specimen for diagnosis of human brucellosis by PCR. J Clin Microbiol 39:1661-1664.

21. Navarro, E.; Fernandez,J.A.; Escribano, J.and Solera, J. 1999. PCR assay for diagnosis of human brucellosis. J Clin Microbiol 37 (5): 1654-1655.

22. Morata, P.; Queipo-Ortuno, M.I.; Reguera,J.M.; Garcia-Ordonez, M.A.; Cardenas, A., Colmenero , J.D 2003.Development and evaluation of a PCR- enzyme-linked immunosorbent assay for diagnosis of human brucellosis. J Clin Microbiol 41: 144-148.

23. Morata, P.; Queipo-Ortuno, M.I.; Reguera,J.M.; Miralles, F.;LopezGonzalez, J.J., Colmenero, J.D 2001. Diagnostic yield of a PCR assay in focal complication of

brucellosis. J Clin Microbiol 39:3743-6.

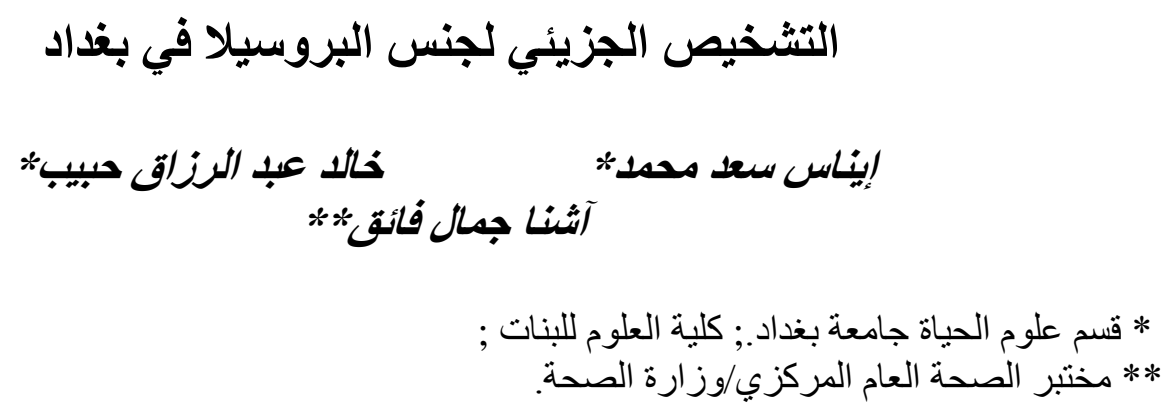

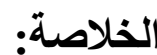

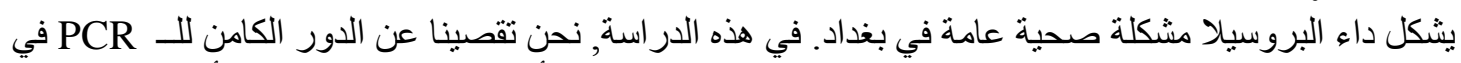

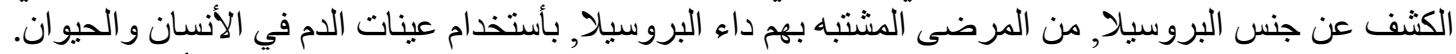

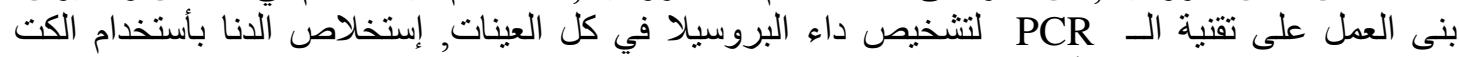

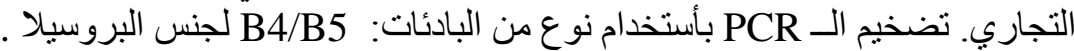

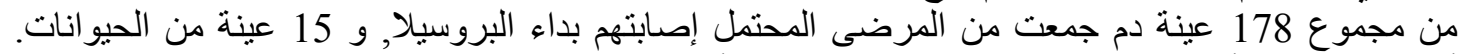

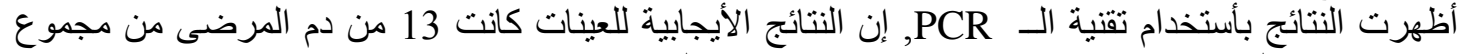
178 و 9 من الحيو انات من مجموع 15 كانت مصابة بداء البروسيلا. 